\title{
Hubungan Tingkat Kemandirian dengan Kualitas Hidup Lanjut Usia di Wilayah Kerja Puskesmas Kelapa Kabupaten Bangka Barat
}

\section{The Correlation Between the Level of Independence and the Quality of Life of the Elderly in Puskesmas Kelapa, West Bangka Regency}

\author{
Nandini Parahita Supraba ${ }^{*}$, Tesza Rezky Permata ${ }^{2}$ \\ 1. Jurusan Kebidanan - Poltekkes Kemenkes Pangkalpinang, Indonesia \\ 2. Jurusan Kebidanan - Poltekkes Kemenkes Pangkalpinang, Indonesia \\ *Email Korespondensi: nandiniparahita29@ gmail.com
}

\begin{abstract}
Abstrak
Latar belakang: Lanjut usia merupakan seseorang yang telah mencapai usia 60 tahun. Banyaknya penurunan fungsi kognitif yang terjadi pada lanjut usia, menuntut lansia dapat menyesuaikan diri dengan penurunan tersebut. Ada beberapa permasalahan yang dihadapi oleh lanjut usia dalam proses penyesuaian diri dengan penurunan fungsi kognitif tersebut yakni diantaranya adanya masalah dalam hal ekonomi, masalah sosial budaya, masalah dalam hal kesehatan, serta bagaimana masalah psikologis yang terjadi pada lansia. Pengaruh peningkatan jumlah lansia akan menimbulkan peningkatan ketergantungan lansia. Diharapkan lansia dapat mempunyai kualitas hidup yang baik serta dapat hidup secara mandiri sehingga dapat mengurangi tingginya angka ketergantungan.

Tujuan: Penelitian ini memiliki tujuan untuk mengetahui hubungan tingkat kemandirian lanjut usia dengan kualitas hidup lansia di Wilayah Kerja Puskesmas Kelapa Kabupaten Bangka Barat.

Metode: Metode yang dipakai dalam penelitian ini adalah cross-sectional analysis (analitik potong lintang). Adapun pendekatan yang dipakai yakni survei kuantitatif. Subjek yang digunakan dalam penelitian ini yakni lansia yang usianya 60 - 74 tahun yaitu sebanyak 32 orang yang dipilih secara purposive sampling.

Hasil: Analisis menunjukkan bahwa ada hubungan yang bermakna dari tingkat kemandirian dengan kualitas hidup ( $\mathrm{p}<0,05)$.

Kesimpulan: Tingkat kemandirian mempunyai hubungan yang bermakna dengan kualitas hidup lanjut usia yang ditunjukkan dari nilai $\mathrm{p}=0,000$, sehingga perawatan lanjut usia melalui kegiatan posyandu lansia yang menjangkau seluruh lansia perlu terus ditingkatkan.
\end{abstract}

Kata kunci: Lansia; Kualitas Hidup; Tingkat Kemandirian

\footnotetext{
Abstract

Background: Elderly is someone who has reached the age of 60 years. The number of declines in cognitive function that occurs in the elderly requires the elderly to be able to adapt to the decline. There are several problems faced by the elderly in the process of adjusting to the decline in cognitive function, including economic problems, socio-cultural problems, health problems, and psychological problems that occur in the elderly. The effect of increasing the number of elderly will lead to an increase in the dependence of the elderly. It is expected that the elderly can have a good quality of life and can live independently to reduce the high rate of dependence.

Objective: This study aims to determine the relationship between the level of independence of the elderly with the quality of life of the elderly in the Puskesmas Kelapa, West Bangka Regency.

Methods: The method used in this study is cross-sectional analytic. The approach used is a quantitative survey. The subjects used in this study were the elderly aged 60-74 years, as many as 32 people were selected by purposive sampling.
} 
Results: The analysis showed that there was a significant relationship between the level of independence and the quality of life $(p<0.05)$.

Conclusion: The level of independence has a significant relationship with the quality of life of the elderly, which is indicated by the p-value $=0.001$, so that elderly care through posyandu activities that reach all the elderly need to be improved.

Keywords: Elderly; Level of Independence; Quality of Life

\section{PENDAHULUAN}

Lansia adalah seseorang yang sudah memasuki umur 60 tahun. Lanjut usia mengalami sangat banyak penurunan pada fungsi kognitifnya. Hal ini menjadikan lanjut usia untuk bisa menyesuaikan diri dengan adanya penurunan pada fungsi kognitif itu. Permasalahan yang akan muncul dalam rangka menghadapi proses penyesuaian diri tersebut yakni masalah dalam hal ekonomi, masalah sosial budaya, masalah kesehatan serta bagaimana masalah psikologis lansia. Tingkatan umur pada lansia menurut WHO (World Health Organization) yaitu umur pertengahan (45-59 tahun), umur lanjut (60-74 tahun), umur lanjut tua (75-84 tahun), umur sangat tua (>84 tahun) (1).

Sensus Penduduk pada tahun 1971 menunjukkan bahwa jumlah penduduk lanjut usia di Indonesia sekitar 5,31 juta jiwa. Lalu terjadi peningkatan pada tahun 2010, hampir empat kali lipat dari jumlah sebelumnya yakni sebanyak 18,04 juta jiwa. Kementrian Kesehatan Republik Indonesia, tahun 2014 mencatat bahwa setiap tahun, Angka Harapan Hidup di Indonesia mengalami peningkatan. Pada tahun 2012, Angka Harapan Hidup di Indonesia yakni 69,87 tahun, angka tersebut lebih tinggi bila dibandingkan dengan Angka Harapan Hidup di Indonesia pada tahun 2011 yakni 69,65 tahun.

Menurut hasil Sensus Penduduk yang dilakukan pada tahun 2010, secara umum jumlah penduduk lanjut usia di Provinsi Kepulauan Bangka Belitung yakni sebanyak 71,27 ribu orang $(5,83 \%)$ dari total seluruh penduduk). Jumlah penduduk lanjut usia yang perempuan sebanyak 37,04 ribu orang, sedangkan jumlah penduduk lanjut usia yang laki-laki yakni 34,23 ribu orang. Adanya perubahan pada struktur penduduk ini dapat menyebabkan dampak pada angka beban ketergantungan. Dampak yang dapat ditimbulkan adalah angka beban ketergantungan penduduk tua. Rasio ketergantungan penduduk lansia (Old Dependency Ratio/ $O D R$ ) adalah angka yang menunjukkan tingkat ketergantungan penduduk lansia pada penduduk usia produktif. Angka tersebut adalah perbandingan antara jumlah penduduk lanjut usia berusia lebih dari 60 tahun dengan jumlah penduduk usia produktif yaitu usia 15-59 tahun. Angka ini menjelaskan bahwa beban ekonomi yang harus ditanggung penduduk usia produktif untuk menanggung biaya penduduk lanjut usia. Rasio ketergantungan penduduk lanjut usia di Provinsi Kepulauan Bangka Belitung pada tahun 2010 yakni sebesar 9,00. Angka rasio 9,00 bermakna 100 orang penduduk usia produktif harus menanggung sembilan orang penduduk lanjut usia. Angka tersebut tentunya semakin meningkat seiring dengan tingginya angka rata-rata harapan hidup penduduk di Indonesia (3).

Proses menua adalah suatu keadaan yang wajar serta tak dapat dihindari di dalam suatu fase kehidupan. Adanya peningkatan jumlah penduduk lanjut usia ini tentu berdampak pada berbagai aspek kehidupan. Adapun dampak yang bisa muncul yakni peningkatan ketergantungan lanjut usia. Ketergantungan lanjut usia ini disebabkan beberapa hal, diantaranya yaitu kemunduran fisik, psikis, serta sosial lansia. Bila lanjut usia memiliki kualitas hidup yang baik serta dapat hidup mandiri maka dapat mengurangi angka ketergantungan (4).

Penduduk lanjut usia merupakan salah satu kelompok sasaran pembangunan dimana hal ini menjadi fokus perhatian dari pemerintah. Perhatian dari berbagai pihak amat diperlukan untuk 
mengantisipasi berbagai permasalahan yang ada kaitannya dengan penuaan penduduk. Perubahan struktur penduduk lanjut usia membawa implikasi pada perumusan serta arah kebijakan pembangunan, salah satunya yakni untuk memberdayakan dan meningkatkan kesejahteraan penduduk lanjut usia (3).

Pemerintah sudah merencanakan berbagai pelayanan bagi lanjut usia baik di bidang sosial maupun bidang kesehatan. Kegiatan yang dilakukan di posyandu lansia misalnya senam lansia yakni di bidang kesehatan pada tingkat masyarakat. Pada tingkat dasar, ada Puskesmas. Sedangkan di tingkat lanjutan ada Rumah Sakit. Upaya tersebut belum maksimal, masih ada lanjut usia dengan kualitas hidup yang kurang (5).

Presentase cakupan pelayanan kesehatan pada lanjut usia di Puskemas Kelapa pada Tahun 2018 dibagi menjadi 4 trimester. Pada trimester pertama sebanyak 14,99\%, trimester kedua 24,68\%, trimester ketiga 35,34\% dan trimester keempat 66,24\%. Presentase cakupan pelayanan kesehatan pada lanjut usia di tahun 2019 selama dua trimester awal yaitu pada trimester pertama sebanyak $24,57 \%$ dan pada trimester kedua 45,42\%. Adapun target lanjut usia (60-74 tahun) di Puskemas Kelapa pada Tahun 2021 yaitu sebanyak `1217 orang (6).

Studi pendahuluan pada 5 lanjut usia yang dilakukan secara random di wilayah kerja Puskesmas Kelapa menunjukkan bahwa salah satu masalah yang sering terjadi adalah masalah kualitas hidup pada lanjut usia. Sebagian besar kualitas hidup pada lanjut usia tersebut kurang yakni sebesar $60 \%$. Kualitas hidup lanjut usia yang kurang lebih banyak terjadi pada lanjut usia yang tingkat kemandiriannya juga kurang (67\%). Oleh karena itu penulis merasa perlu melaksanakan suatu penelitian yang berkaitan dengan hubungan tingkat kemandirian dengan kualitas hidup lanjut usia di Puskesmas Kelapa Kabupaten Bangka Barat.

\section{METODE}

Penelitian ini merupakan penelitian cross-sectional analitik dengan menggunakan pendekatan survei kuantitatif. Subjek yang digunakan dalam penelitian ini merupakan lansia berumur $60-$ 74 tahun yaitu sebanyak 32 orang yang dipilih secara purposive sampling. Lokasi penelitian ini adalah Puskesmas Kelapa Kabupaten Bangka Barat. Lama waktu penelitian ini yaitu 10 (sepuluh) bulan yaitu Januari - Oktober 2020 di Puskesmas Kelapa. Variabel independen adalah tingkat kemandirian lanjut usia dan variabel dependennya yaitu kualitas hidup lanjut usia. Data diperoleh melalui pengisian kuisioner Tingkat Kemandirian Lanjut Usia (7) dan Kualitas Hidup Lanjut Usia (8). Setelah pengumpulan data dilakukan, data diolah menggunakan program SPSS. Penelitian ini sudah dinyatakan laik etik dari Komisi Etik Poltekkes Kemenkes Pangkalpinang dengan nomor 07/EC/KEPK-PKP/IV/2020.

\section{HASIL}

Penelitian ini dilakukan bulan Januari sampai dengan Oktober 2020 mengenai hubungan tingkat kemandirian dengan kualitas hidup lansia di Puskesmas Kelapa. Karakteristik lanjut usia digambarkan di tabel berikut : 
Tabel 1. Hasil Analisis Univariat

\begin{tabular}{lc}
\hline \multicolumn{1}{c}{ Karakteristik } & $\mathbf{f}(\boldsymbol{\%})$ \\
\hline Umur & $12(37,5)$ \\
68-74 tahun & $20(62,5)$ \\
$60-67$ tahun & \\
\hline Jenis Kelamin & $12(37,5)$ \\
Laki - laki & $20(62,5)$ \\
Perempuan & \\
\hline Pendidikan & $32(100)$ \\
Rendah & $0(0)$ \\
Tinggi & $16(50)$ \\
\hline Pekerjaan & $16(50)$ \\
Tidak bekerja & \\
Bekerja & $10(31,25)$ \\
\hline Status Pernikahan & $22(68,75)$ \\
Janda/duda & \\
Menikah & \\
\hline
\end{tabular}

Karakteristik lansia dihubungkan dengan kualitas hidup lansia digambarkan di tabel berikut :

Tabel 2. Karakteristik Responden dengan Kualitas Hidup Lanjut Usia

\begin{tabular}{|c|c|c|c|}
\hline \multirow[b]{2}{*}{ Karakteristik } & \multicolumn{2}{|c|}{ Kategori } & \multirow[b]{2}{*}{ Nilai p } \\
\hline & $\begin{array}{c}\text { Kualitas Hidup } \\
\text { Kurang } \\
\text { f }(\%)\end{array}$ & $\begin{array}{c}\text { Kualitas } \\
\text { Hidup Baik } \\
\text { f (\%) }\end{array}$ & \\
\hline \multicolumn{4}{|l|}{ Umur } \\
\hline 68-74 tahun & $11(91,67)$ & $1(8,33)$ & 0,000 \\
\hline 60-67 tahun & $0(0)$ & $20(100)$ & \\
\hline \multicolumn{4}{|l|}{ Jenis kelamin } \\
\hline Laki - laki & $4(33,33)$ & $8(66,67)$ & 0,923 \\
\hline Perempuan & $7(35)$ & $13(65)$ & \\
\hline \multicolumn{4}{|l|}{ Pendidikan } \\
\hline Rendah & $11(34,38)$ & $21(65,62)$ & - \\
\hline Tinggi & $0(0)$ & $0(0)$ & \\
\hline \multicolumn{4}{|l|}{ Pekerjaan } \\
\hline Tidak bekerja & $8(50)$ & $8(50)$ & 0,063 \\
\hline Bekerja & $3(18,75)$ & $13(81,25)$ & \\
\hline \multicolumn{4}{|l|}{ Status Pernikahan } \\
\hline Janda/duda & $5(50)$ & $5(50)$ & 0,210 \\
\hline Menikah & $6(27,27)$ & $16(72,73)$ & \\
\hline
\end{tabular}


Tingkat kemandirian dengan kualitas hidup lansia digambarkan di tabel berikut :

Tabel 3. Analisis Bivariat

\begin{tabular}{lccc}
\hline \multirow{1}{*}{ Variabel } & \multicolumn{2}{c}{ Kategori } & \\
\cline { 2 - 3 } & $\begin{array}{c}\text { Kualitas Hidup } \\
\text { Kurang } \\
\mathbf{f}(\boldsymbol{\%})\end{array}$ & $\begin{array}{c}\text { Kualitas Hidup } \\
\text { Baik } \\
\mathbf{f ( \% )}\end{array}$ & Nilai p \\
\hline $\begin{array}{l}\text { Tingkat kemandirian } \\
\text { Kurang mandiri }\end{array}$ & $9(90)$ & $1(10)$ & 0,000 \\
Mandiri & $2(9,09)$ & $20(90,91)$ & \\
\hline
\end{tabular}

\section{PEMBAHASAN}

Hasil penelitian didapatkan hubungan yang bermakna antara umur lanjut usia dengan kualitas hidup ( $\mathrm{p}<0,05)$. Pertambahan usia pada lanjut usia menyebabkan perubahan pada cara hidup, salah satunya yaitu merasa kesepian serta sadar akan kematian, hidup sendiri, perekonomian berubah, mengalami penyakit yang kronis, melemahnya kekuatan pada fisiknya, perubahan pada mental, berkurangnya keterampilan psikomotor. Perubahan psikososial yang terjadi yakni pensiun, sumber pendapatan sudah tak ada lagi, kehilangan pasangan serta kehilangan kehadiran teman, tak punya pekerjaan serta semakin sedikitnya kegiatan sehingga hal - hal tersebut dapat mempengaruhi kualitas hidup lanjut usia tersebut (9). Penelitian sebelumnya juga menunjukkan hasil yang sama bahwa umur lanjut usia mempunyai hubungan bermakna dengan kualitas hidup lanjut usia (10). Penelitian di Kota Kediri Provinsi Jawa Timur juga menunjukkan bahwa ada hubungan antara faktor usia dengan kualitas hidup lanjut usia (11).

Hasil penelitian menunjukkan bahwa jenis kelamin tidak berhubungan dengan kualitas hidup lanjut usia ( $>0,05)$. Sesuai dengan teori yang ada (12) bahwa kualitas hidup seorang laki-laki lanjut usia lebih tinggi daripada lansia perempuan. Hasil studinya juga melaporkan bahwa secara signifikan laki-laki lansia memiliki kepuasan yang lebih tinggi dalam beberapa aspek antara lain hubungan personal, bagaimana dukungan keluarga, kondisi ekonomi, pelayanan sosial, kondisi kehidupan dan kondisi kesehatan, lanjut usia yang perempuan mempunyai nilai yang lebih tinggi dalam hal kesepian, rendahnya keadaan ekonomi serta khawatir tentang masa depan. Pada penelitian kali ini tidak terdapat hubungan yang bermakna dari jenis kelamin lansia dengan kualitas hidup. Hal ini dapat terjadi karena lansia perempuan tidak kesepian dan ekonomi cukup yang ditopang oleh adanya dukungan keluarga, kemungkinan lain dapat terjadi juga karena jumlah sampel yang kurang besar sehingga hasil penelitian belum dapat digeneralisasi.

Pendidikan responden seluruhnya tergolong dalam tingkat pendidikan rendah yakni maksimal lulusan SMP. Hal ini juga yang menjadi keterbatasan pada penelitian ini, karena hasil penelitian menunjukkan bahwa pendidikan semua responden dalam kategori rendah dan tidak ada yang berkategori tinggi sehingga tidak dapat dianalisis lebih lanjut. Sebanyak $65,62 \%$ dengan kualitas hidup baik dan sisanya yaitu lanjut usia yang kualitas hidupnya kurang baik. Keadaan ini sesuai dengan pola dalam bidang pendidikan dari kalangan lansia di Indonesia dimana pada umumnya sekitar $71,2 \%$ lansia tersebut belum mengetahui adanya pendidikan formal, sehingga lanjut usia sudah dapat menyesuaikan diri sejak dulu dengan tingkat pendidikan mereka sehingga tidak mempengaruhi keadaan suasana hati, perasaan dan kualitas hidupnya (13).

Penelitian menunjukkan bahwa pekerjaan tidak berhubungan dengan kualitas hidup lansia ( $p>0,05)$. Menurut Nugroho (14) lansia yang tidak mempunyai pekerjaan biasanya mengalami kecemasan serta rasa takut, terutama bergantung pada orang lain terkait keadaan ekonominya. 
Hal tersebut tentu akan mempengaruhi kualitas hidup. Tidak adanya hubungan yang bermakna pada penelitian kali ini penyebabnya adalah karena jumlah sampel yang terlalu kecil.

Pada penelitian kali ini menunjukkan bahwa status pernikahan tidak berhubungan dengan kualitas hidup lanjut usia dimana nilai $p>0,05$. (Berdasarkan penelitian (15) status pernikahan lansia mempengaruhi kualitas hidupnya. Lanjut usia yang hidup seorang diri baik sendiri karena keluarga meninggal maupun keadaan bercerai dari pasangan, memiliki kualitas hidup yang tak sama dengan lanjut usia yang hidup dalam keluarga utuh. Kehilangan pasangan hidup pada lansia pada umumnya banyak disebabkan oleh kematian. Hal ini dikarenakan banyaknya kegiatan yang sebelumnya dilakukan secara bersama dengan pasangan hidupnya kini harus dilaksanakan seorang diri, misalnya membahas tentang masa depan anak, masalah ekonomi rumah tangga maupun tentang hubungan sosial. Tidak adanya hubungan yang signifikan dalam penelitian kali ini mungkin disebabkan karena lansia bisa saja membahas tentang bagaimana masa depan anak - anak mereka maupun masalah tentang perekonomian rumah tangga dengan saudara terdekat, tidak dengan pasangan.

Hasil penelitian menunjukkan bahwa hubungan antara tingkat kemandirian dengan kualitas hidup lanjut usia bermakna dengan nilai $p<0,05$. Menurut Nugroho (14) Lanjut usia yang mempunyai tingkat kemandirian yang tinggi maka kualitas hidup lanjut usia tersebut juga biasanya tinggi juga. Bekal kemandirian lanjut usia tersebut dapat membuat lanjut usia mampu melaksanakan aktivitas sehari-hari. Bagaimana pun juga beberapa aktivitas perlu bantuan orang lain untuk melakukannya. Perihal ini dibahas dalam teori yang dinyatakan oleh Miller (16) yakni bahwa lanjut usia yang memiliki tingkat ketergantungan yang tinggi maka kualitas hidupnya cenderung kurang. Pada perkembangan hidupnya, lansia tentu akan mengalami penurunan pada fungsi tubuhnya. Hal ini akan berdampak pada penurunan fungsi berjalan, penurunan pada keseimbangan, serta penurunan pada kemampuan fungsional lanjut usia tersebut. Tingkat kemandirian pada lansia dapat menurun sehingga hal ini juga akan membuat kualitas hidup lansia tersebut juga otomatis menurun (17).

Kualitas hidup lanjut usia tentu berhubungan dengan bagaimana lansia tersebut menua dengan sukses. Menua dengan sukses ini pada umumnya dikaitkan dengan kesehatan pada fisik lansia tersebut, tingkat kemandirian serta bagaimana kemampuan fungsional lanjut usia (18). Hasil penelitian ini selaras dengan hasil penelitian yang pernah dilakukan sebelumnya oleh (19). Pada penelitian tersebut menyatakan bahwa ada hubungan bermakna antara tingkat kemandirian dengan kualitas hidup lanjut usia di Puskesmas Lubuk Buaya Padang.

Bila seorang lanjut usia semakin mandiri dalam melakukan aktifitasnya sehari-hari maka kualitas hidup lanjut usia tersebut juga akan semakin baik. Penelitian ini didukung oleh penelitian sebelumnya (20). Pada penelitian tersebut dikatakan bahwa terdapat hubungan yang signifikan antara fungsi kognitif dengan tingkat kemandirian lanjut usia. Fungsi kognitif merupakan salah satu faktor yang mempengaruhi tingkat kemandirian. Adanya penurunan fungsi kognitif yang dialami lanjut usia akan mengakibatkan kemampuan lanjut usia dalam melakukan aktivitas sehari- hari menjadi menurun misalnya ketika akan berjalan lanjut usia membutuhkan tongkat ataupun walker yang digunakan untuk mempermudah lansia untuk bergerak. Pada penelitian ini ada 61,8\% lanjut usia yang mengalami gangguan kognitif dan 35,3\% lanjut usia mengalami ketergantungan dalam melakukan aktivitas sehari- hari.

Adanya penurunan kemampuan lanjut usia dalam melaksanakan aktivitasnya akan berdampak pada sifat ketergantungan lanjut usia pada orang lain. Ketergantungan ini berdampak pada penurunan aktivitas lanjut usia. Jika terjadi dalam jangka waktu yang panjang, maka mengakibatkan peningkatan angka kesakitan dan kematian serta berdampak pada kualitas hidup lansia yang cenderung akan menurun (21). 


\section{SIMPULAN}

Hasil penelitian ini menunjukkan bahwa tingkat kemandirian memiliki hubungan yang signifikan dengan kualitas lanjut usia, dibuktikan dengan nilai $\mathrm{p}=0,000$.

\section{SARAN}

Disarankan bagi peneliti selanjutnya agar ketika melakukan penelitian yang sejenis atau tentang kualitas hidup lansia menggunakan jumlah sampel yang lebih besar, agar hasil penelitan lebih memungkinkan untuk dapat digeneralisasi. Selanjutnya, diperlukan juga untuk melakukan penelitian tentang kualitas hidup pada lanjut usia secara kualitatif, sebagai pengembangan dari penelitian ini.

\section{UCAPAN TERIMA KASIH}

Terima kasih yang sebesar-besarnya untuk Poltekkes Kemenkes Pangkalpinang dan Puskesmas Kelapa Bangka Barat yang telah mendukung terselesaikannya penelitian ini.

\section{DAFTAR PUSTAKA}

1. Notoatmodjo. Kesehatan Masyarakat Ilmu dan Seni. Jakarta: PT.Rineka Cipta; 2007.

2. Kemenkes RI. Profil Kesehatan Indonesia Tahun 2013. Jakarta: Kementerian Kesehatan Republik Indonesia; 2014.

3. BPS RI. Statistik Penduduk Lanjut Usia Provinsi Kepulauan Bangka Belitung 2010. Jakarta: BPS; 2010.

4. Yuliati A, Baroya, Ririyanti. Perbedaan Kualitas Hidup Lansia yang Tinggal di Komunitas dengan di Pelayanan Sosial Lanjut Usia ( The Different of Quality of Life Among the Elderly who Living at Community and Social Services ). 2014;2(1):87-94.

5. Depsos RI. Kebijakan dan Program Pelayanan Sosial Lansia. Jakarta: Depsos RI; 2003.

6. Puskesmas Kelapa. Laporan Tahunan Puskesmas Kelapa. 2018.

7. Hardywinoto S. Panduan Gerontologi. Jakarta: Gramedia; 2005.

8. WHO. WHO quality of life BREF. Geneva: World Health Organization; 2004.

9. Nugroho HW. Komunikasi Dalam Keperawatan Gerontik. Jakarta: EGC; 2009.

10. Pradono J, Hapsari D, Sari P. Kualitas Hidup Penduduk Indonesia Menurut International Classification Of Functioning, Disability And Health (ICF) Dan Faktor-Faktor Yang Mempengaruhinya (Analisis Lanjut Data RISKESDAS 2007). Jakarta Pus Penelit dan Pengemb Ekol dan Status Kesehat. 2007;(3).

11. Sutikno E. Hubungan antara Fungsi Keluarga dan Kualitas Hidup Lansia. J Kedokt Indones VOL 2/NO 1/JANUARI/2011. 2007;73-9.

12. Dragomirecka \& Selepova. Do Czech Elderly Women Hhave Lower Quality Of Life Than Men? Results Of A Pilot Study. 2002.

13. Darmojo B. Ilmu Kesehatan Usia Lanjut. Jakarta: FK UI; 2006.

14. Nugroho. Keperawatan gerontik (Edisi 2). Jakarta: EGC; 2000.

15. Suardana IW. Hubungan Faktor Sosiodemografi, Dukungan Sosial dan Status Kesehatan dengan Tingkat Depresi pada Agregat Lanjut Usia di Kecamatan Karangasem Kabupaten Karangasem Bali. Jakarta UI. 2011;

16. Miller C. Nursing Care of Older Adult: Theory and Practice. Philadelphia: Lippincot Company; 2009.

17. Utomo B. Fisioterapi Lanjut Usia. Jakarta: EGC; 2010.

18. Dewi. Buku Ajar Keperawatan Gerontik. Yogyakarta: Deepublish; 2014.

19. Apriana. Hubungan Tingkat Kemandirian Aktifitas Sehari-hari dengan Kualitas Hidup 
Lansia di Keluarahan Tabing Wilayah Kerja Puskesmas Lubuk Buaya Padang. J Kesehat Andalas. 2013;

20. Trihayati. Hubungan Fungsi Kognitif Dengan Tingkat Kemandirian Aktifitas Sehari Hari pada Lansia di UPT Panti Wredha Budhi Dharma Ponggalan Yogyakarta. Univ Aisyiah Yogyakarta. 2016;

21. Maas. Asuhan Keperawatan Geriatrik. Jakarta: EGC; 2011. 